\title{
Risk factors for genital chlamydial infection
}

\author{
Christine Navarro MSc ${ }^{1}$, Ann Jolly BSc MSc PhD ${ }^{2}$, \\ Rama Nair BSc MStat MSc PhD ${ }^{1}$, Yue Chen MD PhD ${ }^{1}$
}

C Navarro, A Jolly, R Nair, Y Chen. Risk factors for genital chlamydial infection. J Sex Reprod Med 2003;3(1):23-34.

OBJECTIVE: To discuss the occurrence of genital chlamydia in developed countries and review the literature assessing the potential risk factors for this sexually transmitted disease.

DATA SOURCES: A MEDLINE search was performed for all English citations from 1985 to 2000 that contain the keywords "Chlamydia trachomatis", "chlamydial infections", "risk factors" and "sex behaviour". All relevant references cited in articles that were obtained from the search were also included.

DATA EXTRACTION: All articles obtained from the above sources were examined, and were included in the review if they met the following criteria: primary study examining sociodemographic or behavioural risk factors associated with genital chlamydial infection using multivariate analysis; study subjects 12 years of age and older; and study setting in a developed country.

DATA SYNTHESIS AND CONCLUSIONS: Genital chlamydial infection has become the most commonly reported bacterial infection in North America over the past decade. Thirty-eight cross-sectional studies and six cohort studies were included in the present review. Most studies demonstrated that young men and women are at higher risk of being infected with chlamydia than older subjects. Chlamydia seems to be found in a diverse group of people, and unlike gonorrhea, is not concentrated in low income, minority core groups with high rates of partner change. However, a number of studies have shown that communities with well-established control programs are beginning to demonstrate this pattern. There is no clear evidence that chlamydia is associated with type of partners, contraceptive use, or age at first intercourse. Future research should follow this sexually transmitted disease as it evolves through the epidemiological stages to ensure that preventive and treatment services are reaching those people who are most likely to be infected.

Key Words: Epidemiology; Genital chlamydia; Risk factors; Sexually transmitted diseases

\section{Les facteurs de risque de chlamidiose génitale}

OBJECTIF : Discuter de l'occurrence de chlamidiose génitale dans les pays industrialisés et examiner la documentation scientifique évaluant les facteurs de risque potentiels de cette maladie transmise sexuellement.

SOURCES DE DONNÉES : Une recherche sur toutes les citations des mots clés "Chlamydia trachomatis ", " chlamidiose ", " facteurs de risque » et « comportement sexuel » entre 1985 et 2000 a été exécutée dans MEDLINE. Toutes les références pertinentes citées dans les articles obtenus grâce à cette recherche ont également été incluses. EXTRACTION DES DONNÉES : Tous les articles obtenus dans les sources précédentes ont été examinés et inclus dans l'analyse s'ils respectaient les critères suivants : étude primaire portant sur les facteurs de risque sociodémographiques ou comportementaux associés avec une chlamidiose génitale au moyen d'une analyse multivariée, étude de sujets de 12 ans et plus et étude menée dans un pays industrialisé.

SYNTHÈSE DES DONNÉES ET CONCLUSION : Depuis dix ans, la chlamidiose génitale est devenue l'infection bactérienne la plus déclarée en Amérique du Nord. Trente-huit études transversales et six études de cohortes ont été incluses dans la présente analyse. La plupart des études ont démontré que les jeunes hommes et femmes courent un risque plus élevés d'être infectés par la chlamydia que les personnes plus âgées. La chlamydia semble s'observer dans un groupe varié de la population et, contrairement à la gonorrhée, elle n'est pas concentrée dans des noyaux minoritaires à faible revenu présentant un roulement élevé de partenaires. Cependant, plusieurs études ont démontré que les collectivités disposant de programmes de contrôle bien établis commencent à afficher ce schème. Il n'existe pas de preuve manifeste selon laquelle la chlamydia est reliée au type de partenaires, à l'usage de contraceptifs ou à l'âge de la première relation sexuelle. Les prochaines recherches devraient porter sur les phases épidémiologiques de cette maladie transmise sexuellement, pour garantir que les services préventifs et de traitements atteignent les personnes les plus susceptibles d'être infectées.
Oenital chlamydial infection is a sexually transmitted disJease (STD) of public health importance. Infection with the intracellular bacterium Chlamydia trachomatis can cause urethritis, cervicitis, pharyngitis, proctitis or epididymitis, although asymptomatic infections are quite common, occurring in up to $70 \%$ of infected women and $50 \%$ of infected men $(1,2)$. Untreated chlamydial infection can lead to pelvic inflammatory disease (PID) in 10\% to $40 \%$ of affected women, which can result in infertility, ectopic pregnancy and chronic pelvic pain $(3,4)$. As well, chlamydial infection during pregnancy may cause complications such as spontaneous abortion, premature rupture of fetal membranes, premature delivery, low birth weight and neonatal infections including conjunctivitis and pneumonia (4-6). The economic burden of this disease is also great. The 1990 baseline burden of illness estimate for C trachomatis in Canada, which includes the costs of diagnostic and screening tests, and treatment of uncomplicated genital chlamydia and cases of PID, female infertility and ectopic preg-

${ }^{1}$ Department of Epidemiology and Community Medicine, Faculty of Medicine, University of Ottawa; ${ }^{2}$ Division of STD Prevention and Control, Bureau of HIVIAIDS, STD and TB, Centre for Infectious Disease Prevention and Control, Health Canada, Ottawa, Ontario

Correspondence: C Navarro, Department of Epidemiology and Community Medicine, University of Ottawa, 451 Smyth Road, Ottawa, Ontario K1H 8M5. Telephone 613-562-5800 ext 8364, fax 613-562-5465, e-mail navarro@zeus.med.uottawa.ca 
nancy attributable to this infection, was $\$ 89$ million for men and women combined (7). In comparison, the direct and indirect costs of treating genital chlamydia and its complications in the United States was estimated to be approximately US $\$ 2$ billion in 1994 (3).

The present paper provides an overview of the occurrence of genital chlamydia in developed countries and summarizes the potential risk factors associated with the disease. These risk factors may be either causally related to disease outcome (such as number of partners or use of barrier contraceptives), a marker or indicator of certain sexual or health care behaviours that directly affect a person's risk of infection (including socioeconomic status or race) or both (such as age). The ability to identify populations at increased risk is important for targeting screening and prevention programs.

\section{DATA AND METHODS}

To find epidemiological studies that examined the risk factors related to genital chlamydial infection, a MEDLINE search was performed for all English citations from 1985 to 2000 that contain the keywords "Chlamydia trachomatis", "chlamydial infections", "risk factors" and "sex behaviour". The reference lists from retrieved articles were searched manually to find further relevant studies. Studies were included in the present review if they met the following criteria: the study was published in 1985 or later; the study was a primary study examining sociodemographic and behavioural risk factors associated with chlamydial infection using multivariate analysis; and study subjects were 12 years of age and older. As well, the study had to be located in Canada, the United States, Australia, New Zealand or Europe, because the epidemiology of genital chlamydia in developing countries is very distinct from that of developed countries, due to differences in health care accessibility, public sector resources, health care-seeking behaviours and gender inequalities (8). Three articles that exclusively compared repeat cases to initial cases of genital chlamydia were excluded $(9-11)$ from this review to make comparisons among studies more meaningful, because all other studies compared infected individuals to individuals who were not infected. In addition, three articles were eliminated because the method of detection for chlamydial infection was not given (12), had low specificity (microimmunofluorescence) (13), or was based solely on self-reported disease status (14). Overall, 44 studies examining risk factors for genital chlamydial infection were included in the review, including 38 cross-sectional studies in which disease and exposure status were assessed at a single time for each study subject, and six prospective cohort studies that examined the predictors of incident infections in susceptible study subjects over a period of time. Only eight of these studies looked at risk factors for chlamydia in males. The studies are described in Tables 1 and 2.

\section{OCCURRENCE OF GENITAL CHLAMYDIA}

Genital chlamydia has become the most commonly reported bacterial STD in North America and Europe (15). However, accurate time trends in the incidence of chlamydia are difficult to define because of changes in reporting, increased detection due to improved laboratory tests and increasing laboratory surveillance (16). Gerbase et al (17) estimated that the average annual incidence rates for people aged 15 to 49 years were similar in North America, western Europe and Australasia at 2146/100,000 for males and 3073/100,000 for females in 1995.
This translates into 1.64 million new cases in males and 2.34 million new cases in females in North America, compared with 2.30 million males and 3.20 million females in western Europe, and 120,000 males and 170,000 females in Australasia.

In Canada, reported genital chlamydial infections decreased steadily between 1991 and 1997, from an annual national reported incidence of $171.7 / 100,000$ persons to $112.7 / 100,000$ persons (18). However, increases in genital chlamydia incidence have been reported by some provinces since 1998, due in part to the introduction of nucleic acid amplification tests that have a substantially higher sensitivity than previous tests (19). In 2000, the annual national reported incidence was $151.1 / 100,000$ persons. Annual reported incidence rates are consistently higher among females than among males. In 2000, the reported incidence rates were highest at $1236.1 / 100,000$ among women aged 15 to 19 years and $1179.4 / 100,000$ among women aged 20 to 24 years. In contrast, the reported incidence of genital chlamydia peaked at $472.8 / 100,000$ among men aged 20 to 24 years in 2000 (18). This sex differential reflects the combination of screening of asymptomatic females during routine pelvic examinations and low rates of testing in men (18).

In the United States, reported incidence rates of genital chlamydia increased from 50.8 cases/100,000 persons in 1987 to $236.6 / 100,000$ in 1998 . In addition to increased screening, especially for asymptomatic women, this trend is also due to improved reporting and an increase in the number of states requiring reporting. As with people in Canada, the incidence was highest in females aged 15 to 19 years, at 2359.4/100,000 cases, and in 20- to 24-year old women, at 1952.7/100,000 in 1998 (20). The 1992 National Health and Social Life Survey found that $3.2 \%$ of 3159 American men and women between the ages of 18 and 59 years reported having had chlamydia in their lifetime, and the annual incidence of chlamydia was estimated to be 500/100,000 population (21). According to the 1988 National Survey of Family Growth (NSFG), 1.7\% (95\% CI 1.4 to 2.0 ) of 8450 women aged 15 to 44 years reported ever having had chlamydia. However, these self-reported rates are likely to be underestimates because chlamydia is a less wellknown STD; for example, only $36.6 \%$ of the NSFG sample had ever heard of chlamydia (14).

In England and Wales, surveillance reports were based on returns from genitourinary medicine (GUM) clinics and microbiological laboratories. In 1996, 29,656 new cases were reported from laboratories and 31,857 new cases were reported from 213 GUM clinics (22). Annual incidence rates for males seen at GUM clinics remained relatively stable - under 100/100,000 males between 1988 and 1996, with highest incidence rates among males aged 20 to 24 years in 1996. For females, the annual incidence increased from 95 cases/100,000 females in 1993 and 125 cases/100,000 females in 1996, with the highest incidence for females aged 16 to 19 years in 1996 (23). However, only about $10 \%$ of $\mathrm{C}$ trachomatis infections are identified in GUM clinics, and reporting from laboratories is neither mandatory nor complete $(22,24)$. Studies and surveillance estimates based on data from STD and GUM clinics also may not provide accurate estimates for the disease frequency among the general population because their clientele are not necessarily representative of the sexually active population that is at risk for STDs (25).

Genital chlamydial infections have been reportable in Swedish laboratories since 1982 and became nationally notifi- 
TABLE 1

Description of cross-sectional studies of chlamydia

\begin{tabular}{|c|c|c|c|c|c|c|}
\hline Year* & Location & $\begin{array}{c}\text { Author } \\
\text { (reference) }\end{array}$ & Study site & $\begin{array}{l}\text { Study } \\
\text { subjects }\end{array}$ & Eligibility criteria & $\begin{array}{l}\text { Primary } \\
\text { method of } \\
\text { detection }\end{array}$ \\
\hline \multirow[t]{2}{*}{1985} & United States & Harrison et al (32) & University clinic & 162 females & Consecutive nonpregnant patients & Culture \\
\hline & United States & $\begin{array}{l}\text { McCormack } \\
\text { et al (33) }\end{array}$ & University clinic & 431 females & Consecutive patients & Culture \\
\hline \multirow[t]{2}{*}{1986} & United States & $\begin{array}{r}\text { Handsfield } \\
\text { et al (70) }\end{array}$ & $\begin{array}{l}\text { Two family planning } \\
\text { clinics }\end{array}$ & 1059 females & $\begin{array}{l}\text { Consecutive patients who have had } \\
\text { intercourse, } \geq 14 \text { years }\end{array}$ & Culture \\
\hline & United States & Karam et al (74) & $\begin{array}{l}\text { Hospital emergency } \\
\text { room }\end{array}$ & 85 males & $\begin{array}{l}\text { Asymptomatic, heterosexual, sexually } \\
\text { active in past three months, } \geq 18 \text { years }\end{array}$ & Culture \\
\hline 1987 & United States & Addiss et al (71) & $\begin{array}{l}\text { Four family planning } \\
\text { clinics }\end{array}$ & 335 females & Patients having a pelvic exam & DFA \\
\hline \multirow[t]{2}{*}{1989} & United States & Oh et al (101) & $\begin{array}{l}\text { One teen family } \\
\text { planning clinic }\end{array}$ & 376 females & Consecutive patients, 12 to 18 years & Culture \\
\hline & United States & Phillips et al (37) & $\begin{array}{l}\text { Four private practices, } \\
\text { one hospital-based } \\
\text { OB/GYN practice }\end{array}$ & 1141 females & $\begin{array}{l}\text { Consecutive nonpregnant patients } \\
\text { having a routine pelvic examination, } \\
18 \text { to } 50 \text { years }\end{array}$ & Culture \\
\hline \multirow[t]{7}{*}{1990} & United States & Addiss et al (87) & $\begin{array}{l}\text { Two family planning } \\
\text { clinics, one community } \\
\text { health centre }\end{array}$ & 849 females & Patients having a pelvic examination & Culture \\
\hline & Denmark & Bro and Juul (91) & 29 general practices & 577 females & $\begin{array}{l}\text { Nonpregnant women complaining of } \\
\text { discharge or having a pelvic } \\
\text { examination }\end{array}$ & Culture \\
\hline & United States & Johnson et al (94) & University clinic & 2271 females & Patients having a pelvic examination & Culture \\
\hline & United Sates & Malotte et al (95) & University clinic & 1320 females & Patients having a pelvic examination & EIA \\
\hline & Canada & Pereira et al (79) & STD clinic & 247 females & Consecutive patients & Culture \\
\hline & $\begin{array}{l}\text { The Nether- } \\
\text { lands }\end{array}$ & $\begin{array}{c}\text { Thewessen } \\
\text { et al (96) }\end{array}$ & $\begin{array}{l}\text { STD and abortion } \\
\text { clinics }\end{array}$ & 1052 females & Consecutive patients & Culture \\
\hline & United States & Winter et al (72) & $\begin{array}{l}\text { Four family planning } \\
\text { clinics }\end{array}$ & 889 females & $\begin{array}{l}\text { Consecutive patients attending for } \\
\text { physical examination or contraceptive } \\
\text { counselling }\end{array}$ & EIA \\
\hline \multirow[t]{2}{*}{1991} & Canada & Masse et al (103) & $\begin{array}{l}\text { One primary health } \\
\text { clinic }\end{array}$ & 717 females & $\begin{array}{l}\text { Patients having a pelvic examination } \\
\text { excluding those presenting specifically } \\
\text { for an STD or who have taken antibiotics } \\
\text { in past six weeks }\end{array}$ & Culture \\
\hline & Canada & $\begin{array}{l}\text { Vincelette } \\
\text { et al (111) }\end{array}$ & 23 provider sites $^{\dagger}$ & $\begin{array}{l}2018 \text { females } \\
838 \text { males }\end{array}$ & $\begin{array}{l}\text { Symptomatic or history of contact with } \\
\text { known or suspected partner or history } \\
\text { of multiple partnerships or presenting for } \\
\text { an abortion }\end{array}$ & EIA \\
\hline \multirow[t]{2}{*}{1992} & Australia & Hart (51) & STD clinic & 3533 females & Consecutive sexually active patients & EIA \\
\hline & United States & Hook et al (78) & STD clinic & $\begin{array}{l}400 \text { females } \\
400 \text { males }\end{array}$ & Consecutive patients & Culture \\
\hline
\end{tabular}


TABLE 1 (CONTINUED)

Description of cross-sectional studies of chlamydia

\begin{tabular}{|c|c|c|c|c|c|c|}
\hline Year* & Location & $\begin{array}{c}\text { Author } \\
\text { (reference) }\end{array}$ & Study site & $\begin{array}{l}\text { Study } \\
\text { subjects }\end{array}$ & Eligibility criteria & $\begin{array}{l}\text { Primary } \\
\text { method of } \\
\text { detection }\end{array}$ \\
\hline & United States & $\begin{array}{l}\text { Humphreys } \\
\text { et al (88) }\end{array}$ & $\begin{array}{l}22 \text { family planning } \\
\text { clinics }\end{array}$ & 11,793 females & Consecutive patients & EIA \\
\hline & Sweden & $\begin{array}{l}\text { Ramstedt } \\
\text { et al (54) }\end{array}$ & Family planning clinics & 5785 females & Consecutive patients, $\leq 25$ years & Culture \\
\hline & Canada & Sellors et al (56) & $\begin{array}{l}\text { Two family planning } \\
\text { clinics }\end{array}$ & 1002 females & $\begin{array}{l}\text { Patients having a pelvic examination, } \\
\geq 16 \text { years }\end{array}$ & $\begin{array}{l}\text { Culture } \\
\text { or EIA }\end{array}$ \\
\hline & United States & $\begin{array}{l}\text { Weinstock } \\
\text { et al (90) }\end{array}$ & $\begin{array}{l}\text { Four family planning } \\
\text { clinics }\end{array}$ & 1348 females & $\begin{array}{l}\text { Consecutive patients attending for } \\
\text { physical examination or contraceptive } \\
\text { counselling who were not screened in } \\
\text { the past year, } 13 \text { to } 50 \text { years }\end{array}$ & DFA \\
\hline \multirow[t]{6}{*}{1993} & United States & Addiss et al (81) & $\begin{array}{l}\text { Five family planning } \\
\text { clinics }\end{array}$ & 1757 females & All patients having a pelvic examination & $\begin{array}{c}\text { DFA } \\
\text { (nonurban) } \\
\text { EIA } \\
\text { (urban) }\end{array}$ \\
\hline & $\begin{array}{l}\text { United } \\
\text { Kingdom }\end{array}$ & Evans et al (92) & $\begin{array}{l}\text { Genitourinary medicine } \\
\text { clinic }\end{array}$ & 1025 females & Consecutive, new attenders & Culture \\
\hline & United States & Han et al (73) & 10 provider sites $^{\dagger}$ & 1531 females & Different criteria at sites & Culture \\
\hline & Australia & Hart (50) & STD clinic & $\begin{array}{l}6125 \text { females } \\
12,170 \text { males }\end{array}$ & Consecutive patients & EIA \\
\hline & Australia & Hart (52) & STD clinic & 7992 males & Consecutive patients & EIA \\
\hline & United States & $\begin{array}{r}\text { Stergachis } \\
\text { et al (55) }\end{array}$ & $\begin{array}{l}\text { Two primary care } \\
\text { clinics }\end{array}$ & 1804 females & $\begin{array}{l}\text { Symptomatic or having a pelvic exam- } \\
\text { ination in clinic A or randomly chosen } \\
\text { at clinic B, } 15 \text { to } 34 \text { years }\end{array}$ & Culture \\
\hline 1995 & Canada & Jolly et al (53) & $\begin{array}{l}\text { Public health laboratory } \\
\text { reports }\end{array}$ & 400 females & $\begin{array}{l}\text { Random sample of those tested at } \\
\text { public health laboratory }\end{array}$ & EIA \\
\hline \multirow[t]{2}{*}{1996} & United States & Finelli et al (93) & $\begin{array}{l}\text { Five STD, five family } \\
\text { planning and five } \\
\text { college health clinics }\end{array}$ & 5128 females & $\begin{array}{l}\text { Patients presenting for a pelvic } \\
\text { examination or symptoms, } 12 \text { to } 29 \text { years }\end{array}$ & EIA \\
\hline & United States & $\begin{array}{l}\text { Gershman } \\
\text { et al (68) }\end{array}$ & $\begin{array}{l}52 \text { family planning } \\
\text { clinics }\end{array}$ & 12,926 females & $\begin{array}{l}\text { Patients having a pelvic examination, } \\
\text { presenting for symptoms, a history } \\
\text { of risk or a recent contact with a } \\
\text { partner with STD }\end{array}$ & $\mathrm{NAH}$ \\
\hline 1997 & United States & Han et al (24) & $\begin{array}{l}\text { Four family planning } \\
\text { clinics }\end{array}$ & 8920 females & $\begin{array}{l}\text { Patients having a pelvic exam or } \\
\text { presenting symptoms }\end{array}$ & EIA \\
\hline & United States & $\begin{array}{l}\text { Marrazzo } \\
\text { et al (36) }\end{array}$ & 12 provider sites $^{\dagger}$ & $\begin{array}{l}4968 \text { females } \\
5150 \text { males }\end{array}$ & Consecutive patients, $\geq 12$ years & LCR \\
\hline & United States & Mosure et al (89) & $\begin{array}{l}160 \text { family planning } \\
\text { clinics }\end{array}$ & $\begin{array}{l}148,650 \\
\text { females }\end{array}$ & $\begin{array}{l}\text { Sexually active patients having a pelvic } \\
\text { examination, } 15 \text { to } 19 \text { years }\end{array}$ & DFA \\
\hline & $\begin{array}{l}\text { The Nether- } \\
\text { lands }\end{array}$ & $\begin{array}{l}\text { Van Duynhoven } \\
\text { et al (25) }\end{array}$ & STD clinic & $\begin{array}{l}1288 \text { females } \\
1696 \text { males }\end{array}$ & Consecutive patients & $\begin{array}{l}\text { Culture } \\
\text { and NAH }\end{array}$ \\
\hline
\end{tabular}


TABLE 1 (CONTINUED)

Description of cross-sectional studies of chlamydia

\begin{tabular}{|c|c|c|c|c|c|c|}
\hline Year* & Location & $\begin{array}{c}\text { Author } \\
\text { (reference) }\end{array}$ & Study site & $\begin{array}{l}\text { Study } \\
\text { subjects }\end{array}$ & Eligibility criteria & $\begin{array}{l}\text { Primary } \\
\text { method of } \\
\text { detection }\end{array}$ \\
\hline 1998 & $\begin{array}{l}\text { United } \\
\text { Kingdom }\end{array}$ & $\begin{array}{l}\text { Oakeshott } \\
\text { et al (97) }\end{array}$ & 30 general practices & 1049 females & $\begin{array}{l}\text { Consecutive patients attending for a } \\
\text { cervical smear test, }<35 \text { years }\end{array}$ & EIA \\
\hline 1999 & Denmark & Munk et al (77) & $\begin{array}{l}\text { Population-based } \\
\text { survey }\end{array}$ & 522 females & $\begin{array}{l}\text { Randomly selected from a population- } \\
\text { based cohort, } 20 \text { to } 29 \text { years }\end{array}$ & PCR \\
\hline & Belgium & $\begin{array}{l}\text { Vuylsteke } \\
\text { et al (35) }\end{array}$ & $\begin{array}{l}17 \text { school medical } \\
\text { centres }\end{array}$ & 1433 females & $\begin{array}{l}\text { Students due for medical check-up, } \\
\text { ever had intercourse, } 16 \text { to } 18 \text { years }\end{array}$ & LCR \\
\hline
\end{tabular}

${ }^{*}$ Year of publication; ${ }^{\dagger} A$ combination of provider sites may include any of the following: family planning clinics, private physician offices, obstetrics/gynecology clinics, emergency rooms, hospital outpatient clinics, correctional centres, student health centres, adolescent clinics, abortion clinics or STD clinics; DFA Direct fluorescent antibody; EIA Enzyme immunoassay; LCR Ligase chain reaction; NAH Nucleic acid hybridization; OB/GYN Obstetrics/Gynecology; PCR Polymerase chain reaction; STD Sexually transmitted disease

TABLE 2

Description of prospective cohort studies of chlamydia

\begin{tabular}{|c|c|c|c|c|c|c|}
\hline Year* $^{*}$ & Location & $\begin{array}{c}\text { Author } \\
\text { (reference) }\end{array}$ & Study site & $\begin{array}{l}\text { Study } \\
\text { subjects }\end{array}$ & Eligibility criteria & $\begin{array}{l}\text { Primary } \\
\text { method of } \\
\text { detection }\end{array}$ \\
\hline 1991 & Sweden & Rahm et al (104) & One adolescent clinic & 301 females & Sexually active adolescent attenders & Culture \\
\hline 1994 & Netherlands & Prins et al (98) & STD clinic & $\begin{array}{l}234 \text { females } \\
155 \text { males }\end{array}$ & $\begin{array}{l}\text { Consecutive patients, heterosexual, } \\
\text { reported } \geq 5 \text { partners in the past six } \\
\text { months, } \geq 18 \text { years }\end{array}$ & Culture \\
\hline \multirow[t]{2}{*}{1996} & United States & Mosure et al (69) & $\begin{array}{l}160 \text { family planning } \\
\text { clinics }\end{array}$ & 26,921 females & $\begin{array}{l}\text { Sexually active patients having a pelvic } \\
\text { examination who were tested for } \\
\text { chlamydia on two or more occasions } \\
\text { between } 1988 \text { and } 1992,15 \text { to } 19 \text { years }\end{array}$ & DFA \\
\hline & United States & Oh et al (99) & Adolescent clinics & 216 females & $\begin{array}{l}\text { Sexually active patients having pelvic } \\
\text { examinations who had at least two visits } \\
\text { with indications for repeat screening during } \\
\text { the study period }\end{array}$ & Culture \\
\hline \multirow[t]{2}{*}{1998} & United States & Burstein (34) & $\begin{array}{l}\text { Three middle school } \\
\text { clinics }\end{array}$ & 188 females & Consecutive patients & LCR \\
\hline & United States & $\begin{array}{l}\text { Burstein } \\
\text { et al (82) }\end{array}$ & $\begin{array}{l}\text { Family planning, STD } \\
\text { and school-based } \\
\text { clinics }\end{array}$ & 3202 females & Consecutive patients, 12 to 19 years & PCR \\
\hline
\end{tabular}

*Year of publication. DFA Direct fluorescent antibody; LCR Ligase chain reaction; PCR Polymerase chain reaction; STD Sexually transmitted disease

able in 1988 (26). The incidence of genital chlamydia began to decrease during the late 1980s, in association with the implementation of routine screening of women, increased screening among men, contact tracing and the establishment of youth clinics (16,26-29). The number of reported cases dropped from approximately 40,000 cases in 1987 to 14,000 cases in 1996 , which has been accompanied by a corresponding reduction in the number of cases of PID and ectopic pregnancy (29-31).

\section{RISK FACTORS FOR GENITAL CHLAMYDIA}

A summary of the relationships between genital chlamydia and the various risk factors observed in the studies reviewed is shown in Tables 3 and 4.
Age

Younger age is shown consistently to be associated with increased risk of chlamydial infection among the sexually active population. Highest incidence rates of infection are reported consistently in adolescents and young adults in Canada and the United States $(18,20)$. Twenty-nine of 34 studies of females and five of seven studies of males have shown a significant relationship between age and chlamydial infection in multivariate analysis. In the majority of studies that did not demonstrate an association between age and chlamydial infection, study populations were restricted to adolescents and young adults, such as at university health services or school-based clinics, where the risk of being infected was 
more likely to be uniform across the subpopulation (32-36). Phillips et al (37) set the cut-off age at 30 years, which may have been too high to detect an age differential; in fact, they did find that women aged 24 years and younger had the highest prevalence of chlamydia.

There are a number of reasons why adolescents are at greater risk for genital chlamydial infection than older people. A higher risk in adolescent females may be associated with certain aspects of physical development that make this group more vulnerable to sexually transmitted infections, including the persistence of columnar epithelium on the cervix, which supports the growth of $\mathrm{C}$ trachomatis, and changes in vaginal flora and mucus production $(38,39)$. As well, older women may have acquired partial immunity after initial or serial infections in the past (6). Differences in the prevalence of infection between adolescents and adults are also often attributed to differences in sexual behaviours. In the United States, the proportion of adolescent women who reported having had premarital intercourse increased from $28.6 \%$ in 1970 to $51.5 \%$ in 1988 (40), and sexual debut during early adolescence is often associated with greater numbers of sex partners (40-44). The difference in number of sexual partners according to age may also largely be a function of marital status (41). Finally, adolescents may be less able to implement the complex act of correct condom use (39) or to communicate effectively about sexuality (45), and may be less likely to acknowledge the risks associated with their sexual behaviour (46). Therefore, in addition to universal screening for adolescents and young adults, as is generally recommended $(47,48)$, these results also highlight the need for more proactive sexual health education strategies for adolescents and young adults for the primary prevention of chlamydia and other STDs.

\section{Race and/or ethnicity and socioeconomic status}

The relationships among race, socioeconomic status (SES) and genital chlamydial infection are not clear. Race/ethnicity and socioeconomic status are often considered together because they are strongly interrelated (49). Only 10 of 23 studies in females and one of four studies in males indicated a higher risk of chlamydial infection in nonwhite people compared with white people in multivariate analysis. SES was not associated with chlamydia in multivariate analysis using any measure for males and females, including employment status (50-52), income (53-55), level of parents' education (33), use of Medicaid (37) or occupation (56).

Although gonorrhea is often shown to be concentrated in low income, minority communities (57-59), genital chlamydial infection does not seem to demonstrate this pattern $(9,60,61)$. One potential reason why such a clearly delineated high-risk or 'core' group was not identified for chlamydia in these studies is that these two STDs are likely to be at different epidemiological stages. In other words, while genital chlamydial infection is still widely prevalent throughout the sexually active population, gonorrhea has become concentrated in those segments of the population that have low or no access to well-established prevention and treatment programs for gonorrhea (62). The distribution of an STD in a population is also influenced by the various combinations of sexual, health care and provider behaviours (51). For example, gonorrhea is often more prevalent in low-income, minority communities than higher-income, white communities $(63,64)$. Because it is generally recommended that people with gonorrhea and their partners also be treated for chlamydia $(47,65)$, the rate of chlamydial infection in some low-SES minority communities may be lower than expected because of frequent exposure to dual antibiotic treatment (60). Race and SES may also be markers for health care seeking behaviours. Poor, uninsured, minority patients may be less likely to seek medical care or to seek care later than their more affluent, insured, nonminority counterparts (66). For instance, women of higher SES may be more likely to have routine examinations, and thus, the detection of asymptomatic cases in this group may bias reporting of chlamydia upward. Nevertheless, after the establishment of coordinated screening, surveillance and health education for chlamydia, this STD, in time, may become more concentrated within core groups where access to STD services is limited. This pattern has already been observed in areas where chlamydia control programs have been introduced $(61,67)$. In fact, race is shown to be an important risk factor in most studies published after 1994, including three studies in which a chlamydia control program was well-established $(24,68,69)$. Further evidence of the potential for such core groups is given in three studies that demonstrated that nonwhite men and women were significantly more likely to have recurrent chlamydial infections than white study subjects $(9-11)$.

Three methodological issues should be mentioned. First, a number of studies that did not demonstrate a significant relationship between racial group and chlamydia had samples that were either predominantly white or predominantly black $(32,50,70-74)$, and a small proportion of subjects with the exposure of interest make it difficult to detect differences among groups. Second, some studies may be affected by a diagnostic bias. For example, if providers are more likely to screen for and report cases of chlamydia in nonwhites, these cases may be systematically over-represented in the study (12). Third, definitions of race may not be clear, especially for those individuals of mixed parentage, which may result in misreporting of this potential risk factor or inconsistencies between studies (75).

In general, although SES does not seem to be a salient risk factor for chlamydia at this point in time, a person's racial or ethnic group has become a more important risk factor in the past few years. Although race should not necessarily be used as a screening criterion, it may be a marker for other underlying problems, including sexual and health care seeking behaviours or SES $(75,76)$. A deeper understanding of the relationship between SES and race and/or ethnicity is required. Race is a characteristic that is not modifiable, but it does present an opportunity for improving primary prevention in communities where this is an important factor, such as through culturally sensitive education programs.

\section{Number and type of partners}

Multiple partnerships may increase the likelihood of encountering a sexually transmitted pathogen through the increased probability of choosing a partner with infection, while having new or casual sexual contacts may be related to increased risk because of a reduced familiarity between partners (21).

Munk et al (77) used polymerase chain reaction to detect $\mathrm{C}$ trachomatis in 525 women who were randomly selected from a population-based cohort. Women who reported having five to nine partners in their lifetime were almost five times more likely to have genital chlamydia than women who reported four or fewer lifetime sexual partners (OR 4.8, 95\% CI 1.8 to 12.7). However, women who reported 10 or more lifetime sex- 
TABLE 3

Risk factors for chlamydia in females

\begin{tabular}{|c|c|c|c|c|c|c|c|c|c|c|c|c|c|}
\hline Year $^{*}$ & $\begin{array}{l}\text { Author } \\
\text { (reference) }\end{array}$ & Age & Race & $\begin{array}{l}\text { Socio- } \\
\text { economic } \\
\text { status }\end{array}$ & \multicolumn{3}{|c|}{ Number of partners } & \multicolumn{3}{|c|}{ Type of partners } & $\begin{array}{l}\text { Barrier } \\
\text { contra- } \\
\text { ceptive } \\
\text { use }\end{array}$ & $\begin{array}{l}\text { Oral } \\
\text { contra- } \\
\text { ceptive } \\
\text { use }\end{array}$ & $\begin{array}{c}\text { Age at } \\
\text { first } \\
\text { inter- } \\
\text { course }\end{array}$ \\
\hline \multirow[t]{2}{*}{1985} & Harrison et al (32) & $\dagger$ & - & & - & & - & & & & & + & \\
\hline & $\begin{array}{l}\text { McCormack } \\
\text { et al (33) }\end{array}$ & - & + & - & + & - & & & & & - & - & \\
\hline 1986 & Handsfield et al (70) & + & - & & & $\dagger$ & $\dagger$ & + & & & + & & - \\
\hline 1987 & Addiss et al (71) & + & - & & & - & & $\dagger$ & & & & - & \\
\hline \multirow[t]{2}{*}{1989} & Oh et al (101) & & & & & & & & & & & + & \\
\hline & Phillips et al (37) & $\dagger$ & + & - & & & - & & & & $\dagger$ & & $\dagger$ \\
\hline \multirow[t]{7}{*}{1990} & Addiss et al (87) & + & $\dagger$ & & & + & $\dagger$ & $\dagger$ & & & $\dagger$ & $\dagger$ & $\dagger$ \\
\hline & Bro and Juul (91) & + & & & & & & & & & $\dagger$ & $\dagger$ & \\
\hline & Johnson et al (94) & & - & & & & + & + & & & - & - & \\
\hline & Malotte et al (95) & + & & & & & $\dagger$ & + & & & - & $\dagger$ & \\
\hline & Pereira et al (79) & + & & & - & & - & & & & - & + & - \\
\hline & Thewessen et al (96) & + & & & & & + & & & & - & $\dagger$ & \\
\hline & Winter et al (72) & + & - & & & & - & & & & $\dagger$ & $\dagger$ & \\
\hline \multirow[t]{3}{*}{1991} & Masse et al (103) & + & & & & - & & - & & & & - & \\
\hline & Rahm et al (104) & & & & & $\dagger$ & & & & & & - & \\
\hline & Vincelette et al (110) & + & & & & + & & & & & & & \\
\hline \multirow[t]{6}{*}{1992} & Hart (51) & + & + & - & & & - & & & + & & + & \\
\hline & Hook et al (78) & + & & & - & - & - & - & - & - & & & - \\
\hline & Humphreys et al (88) & + & & & & + & & + & & & + & - & \\
\hline & Ramstedt et al (54) & + & & $\dagger$ & & & & & & & + & & \\
\hline & Sellors et al (56) & $\dagger$ & & $\dagger$ & & & & + & & & & & \\
\hline & Weinstock et al (90) & + & $\dagger$ & & & & & + & & & + & - & \\
\hline \multirow[t]{6}{*}{1993} & Addiss et al (81) & + & & & & + & $\dagger$ & $\dagger$ & & & + & - & \\
\hline & Evans et al (92) & + & $\dagger$ & & - & + & & & & & - & $\dagger$ & $\dagger$ \\
\hline & Han et al (73) & + & - & & & & + & & & & & + & \\
\hline & Hart (50) & + & - & - & & & - & & & + & & + & \\
\hline & Stergachis et al (55) & + & + & $\dagger$ & & + & & - & & & - & - & \\
\hline & Prins et al (98) & + & & & & & & - & & & & & \\
\hline 1995 & Jolly et al (53) & + & + & - & & & & & & & & & \\
\hline \multirow[t]{3}{*}{1996} & Finelli et al (93) & + & $\dagger$ & & & & & & & & - & & \\
\hline & Gershman et al (68) & + & + & & & & + & $\dagger$ & & & & & \\
\hline & Mosure et al (69) & & + & & & & + & + & & & + & + & \\
\hline \multirow[t]{5}{*}{1997} & Han et al (24) & + & + & & & & + & & & & & - & \\
\hline & Marrazzo et al (36) & + & - & & & & + & & & & - & & \\
\hline & Mosure et al (89) & & + & & & & + & + & & & + & + & \\
\hline & Oh et al (99) & & - & & - & & - & & & & - & & \\
\hline & $\begin{array}{l}\text { Van Duynhoven } \\
\text { et al (25) }\end{array}$ & + & & & + & & & & & & + & + & \\
\hline \multirow[t]{3}{*}{1998} & Burstein et al (34) & & & & & & - & - & & & - & & \\
\hline & Burstein et al (82) & & & & & & + & $\dagger$ & & & + & & \\
\hline & Oakeshott et al (97) & + & + & & & + & & & & & - & & \\
\hline \multirow[t]{2}{*}{1999} & Munk et al (77) & + & & & + & & & & & & - & & \\
\hline & Vuylsteke et al (35) & $\dagger$ & & & + & $\dagger$ & & & & & $\dagger$ & & $\dagger$ \\
\hline
\end{tabular}

*Year of publication; ${ }^{\dagger}$ Positive correlation, statistically significant in single factor analysis only; +Positive correlation, statistically significant in multivariate analysis; -No correlation; Blank space Not determined 
TABLE 4

Risk factors for chlamydia in males

\begin{tabular}{|c|c|c|c|c|c|c|c|c|c|c|c|c|}
\hline \multirow[b]{2}{*}{ Year* } & \multirow{2}{*}{$\begin{array}{l}\text { Author } \\
\text { (reference) }\end{array}$} & \multirow[b]{2}{*}{ Age } & \multirow[b]{2}{*}{ Race } & \multirow{2}{*}{$\begin{array}{l}\text { Socio- } \\
\text { economic } \\
\text { status }\end{array}$} & \multicolumn{3}{|c|}{ Number of partners } & \multicolumn{3}{|c|}{ Type of partners } & \multirow{2}{*}{$\begin{array}{c}\text { Barrier } \\
\text { contra- } \\
\text { ceptive } \\
\text { use }\end{array}$} & \multirow{2}{*}{$\begin{array}{c}\text { Age at } \\
\text { first } \\
\text { inter- } \\
\text { course }\end{array}$} \\
\hline & & & & & Lifetime & & Recent & New & Casual & Regular & & \\
\hline 1986 & Karam et al (74) & + & - & & $\dagger$ & + & - & & & & & - \\
\hline 1991 & Vincelette et al (111) & + & & & & - & & & & & & \\
\hline 1992 & Hook et al (78) & - & & & & & - & + & + & - & & \\
\hline \multirow[t]{2}{*}{1993} & Hart (50) & + & - & - & & & + & & & - & & \\
\hline & Hart (52) & + & - & - & & & + & & & $\dagger$ & & \\
\hline 1994 & Prins et al (98) & & & & & & - & & & & & \\
\hline \multirow[t]{2}{*}{1997} & $\begin{array}{l}\text { Van Duynhoven } \\
\text { et al (25) }\end{array}$ & + & & & & & + & & $\dagger$ & & + & \\
\hline & Marrazzo et al (36) & $\dagger$ & + & & & & + & & & & + & \\
\hline
\end{tabular}

${ }^{*}$ Year of publication; ${ }^{\dagger}$ Positive correlation, statistically significant in single factor analysis only; +Positive correlation, statistically significant in multivariate analysis; -No correlation; Blank space Not determined

ual partners had a reduced risk of having chlamydia (OR 2.8, 95\% CI 0.9 to 8.8). The authors suggested that women with multiple sex partners acquire immunity against chlamydial infection from repeated exposure, although this immunity may be strain-specific or short-lived. Van Duynhoven et al (25) documented a similar pattern for women at an STD clinic in the Netherlands, while McCormack et al (33) found that the risk of being seropositive for $\mathrm{C}$ trachomatis antibodies increases with greater numbers of lifetime sex partners for women. Hook et al (78) also found that, for both men and women, those reporting the highest number of lifetime partners (30 or more) had a lower proportion of chlamydia diagnoses than those reporting fewer partners. This trend was not documented in several other studies because the number of lifetime partners was measured as a dichotomous variable $(32,35,74,79)$. The number of partners in the past year may also be an important risk factor for infection in women, because 10 of 14 studies found a positive correlation between multiple partners and infection in either single factor or multivariate analysis.

However, the relationship between the number of recent partners (in the past one, two, three or six months), type of sex partners (new, casual or regular) and genital chlamydia is not consistent across the studies for males or females. This may be partly explained by using the classic model for the transmission of STDs, which defines the reproductive rate $\left(R_{0}\right)$, or the mean number of new infections generated by an infected person over the lifetime of his or her infection, as a product of the probability of transmission from an infected to uninfected person $(\beta)$, the rate of sex partner change (c), and the average duration of infectivity (D) $(3,62,80)$.

$$
R_{0}=\beta c D
$$

Because chlamydia is frequently asymptomatic or only mildly symptomatic, it often goes untreated. The duration of infectivity is therefore often long, and the rate of partner change can remain low for the disease to be sustained in a given population (80). With the implementation of control programs, more asymptomatic cases are treated, causing the duration of infectivity to decrease, and therefore, the rate of partner change must increase correspondingly to maintain the STD in the population (62). As a result, the STD becomes concentrated in the small proportion of the population that is characterized by high rates of new partner acquisition or the 'core' group $(61,80)$. As with race and SES, as chlamydia control programs become more widely established, there will likely be an increase in the importance of the number and type of partners in determining risk of genital chlamydial infection. This pattern has been demonstrated in areas where chlamydia control programs have been in place for a year or more. In all five studies set in populations with well-established screening programs, reporting recent multiple partnerships was significantly associated with a 1.2 to 2.2 -fold increase in risk in multivariate analysis $(24,68,69,81,82)$. In three of those studies, reporting having a new partner was significant before adjusting for other variables $(68,81,82)$, and in Mosure et al's (69) study, published in 1996, this variable was significant in multivariate analysis (OR 1.7, 95\% CI 1.5 to 1.9 ).

Another possible explanation for those inconsistencies may be that the relationship between the number and type of partners and chlamydial infection may be offset by other behaviours. For instance, in the 1991 United States National Survey of Men, men who reported having multiple partners and onenight stands were significantly more likely to report using condoms than men who did not report these behaviours $(41,83)$. There are also methodological reasons for the inconsistency between reported number and type of partners, and chlamydial infection. First, the time frame of the question may bias the observed relationships. Because of the high proportion of asymptomatic cases and the relatively long incubation period for symptomatic cases (seven to 21 days) $(84,85)$, cases that are detected are less likely to be newly acquired $(25,55,61,78)$. Therefore, reporting new or casual partners in the past one to three months may be a less relevant risk behaviour because the most recent partner(s) may not be the source of the infection. Second, the results may be biased because these behaviours are self-reported. It is possible that men over-report the number of sexual partners while women under-report in effort to provide more socially desirable responses (86). As well, the classifica- 
tion of a sexual relationship by its partners may be discordant (78). Differential misclassification may over- or underestimate the association between the exposure and outcome. Third, information on the number and type of partners does not tell whether partners are concurrent or sequential, or commercial or private, the frequency of sex, the sexual practices that are engaged in, or the type of contraceptive that is employed, all of which are factors that can influence a person's risk of infection (21).

\section{Contraceptive use}

The relationship between the use of condoms and other barrier contraceptives (diaphragm or cervical cap), and genital chlamydial infection is inconsistent across the studies. Use of a barrier method was shown to be associated with reduced risk of infection compared with the use of other methods of contraception in two of five studies in females $(33,54,70,71,87)$. Compared with no contraceptives, use of a barrier method was protective against chlamydia for females in three of five studies $(32,69,81,88,89)$. Only one of 10 studies found female barrier users to be significantly less likely to be infected than female nonusers $(37,55,79,90-96)$. Although these studies did not consider consistency of use, when this factor is accounted for, the results are similar. Consistent users of barrier contraceptives were not shown to have a significantly reduced risk of infection compared with inconsistent users in multivariate analysis in six studies in women and one study in men $(25,34,35,72,82,97)$. Han et al (24) found that unprotected sex in the past three months was associated with almost twice the risk of having chlamydia compared with not having unprotected sex for two of four samples from New York family planning clinics. Prins et al (98) did not find a significant relationship between chlamydial infection and the estimated number of unprotected sexual encounters with commercial or private partners for men or women. Using a condom at the last sexual encounter was not significantly associated with decreased risk of infection for female adolescents in Oh et al's study (99), but it was protective for adolescent males in the study by Marrazzo et al (36).

There are three possible reasons for these inconsistencies. First, individuals may have become infected before barrier use and started to use barriers after their symptoms appeared. Second, individuals may over-report barrier contraceptive use. Third, it is unclear how best to measure consistent and correct barrier use (100). Some studies established a time frame for use (eg, past three months, last sexual encounter), while others measured 'current' use of barriers. However, despite these weak results, this risk factor is modifiable, and consistent use of barrier contraceptives, especially condoms, should be encouraged.

Use of oral contraceptive pills (OCP) is thought to increase the risk of chlamydial infection by inducing ectopy, making more cervical epithelial cells susceptible to infection. Alternatively, ectopy induced by OCP may make sampling more efficient and thus improve detection of C trachomatis by culture $(77,101,102)$. Users of OCP may also be less likely to use barrier contraceptives. OCP users tend to have higher prevalences of infection compared with nonusers, but this association is not significant after adjusting for other variables in the majority of studies reviewed $(24,32,33$, $51,55,56,72,81,87,90-92,94,95,103,104)$. Only two studies found that oral contraceptive users were significantly more likely to have chlamydia than nonusers after controlling for other risk factors $(69,79)$, while Mosure et al (89) found that OCP users had a $20 \%$ decreased risk of being infected with chlamydia compared with females who did not use any method of contraception. Therefore, the relationship between OCP use and chlamydial infection is not clear. Harrison et al (32) suggested that cervical ectopy is a better predictor of infection. In their study, cervical ectopy was correlated significantly with use of OCP, while chlamydial infection was related strongly to ectopy, regardless of contraceptive practice. However, while eight of 10 studies examining this risk factor found that women with cervical ectopy were more likely to be infected with $\mathrm{C}$ trachomatis $(32,55,70,72,81,94,96,103)$, only two of those studies showed this relationship to be significant after adjusting for other variables $(55,94)$.

Evans et al (92) found that the use of an intrauterine device (IUD) was protective compared with nonuse (relative risk 0.4 , 95\% CI 0.2 to 0.9 ). The authors hypothesized that the IUD may enhance local immune function or may accelerate the development of squamous cells in the cervical epithelium, which discourages infection by $\mathrm{C}$ trachomatis. However, no significant difference was found for IUD use compared with the use of other methods in two studies $(33,79)$ or for IUD use compared with nonuse in three studies $(50,91,96)$.

\section{Age at first intercourse}

Age at first intercourse may be causally related to sexually transmitted infections through the biological mechanisms affecting adolescents that were discussed earlier (16). It may also be an indicator of other aspects of sexual activity that will directly increase risk, including multiple partnerships and the recruitment of nonregular partners $(44,105,106)$. Four of seven studies that looked at this risk factor found a higher risk of infection in women who had early age of sexual debut in single factor analysis, but none of these studies demonstrated a significant relationship in multivariate analysis. Karam et al (74) found no relationship between age at first intercourse and chlamydial infection in men; however, the sample size of 85 males may have been too small to detect statistically significant differences between groups. There is some evidence that age at sexual debut may be modifiable (107), but it may be equally important to examine the causes of early age at sexual debut and its determinants, such as sexual abuse, to establish the best point of intervention.

\section{Other risk factors}

A number of other risk factors have been identified (through multivariate analysis) to be associated with genital chlamydial infection. Chlamydia rates tend to be highest in men and women who are single, although only three studies identified marital status as a significant risk factor in multivariate analysis $(52,55,90)$. The effect of marital status is mediated largely through its impact on number of partners $(105,108,109)$. Current pregnancy was associated with a 1.4- to 1.8-fold risk of being infected in three studies $(50,88,89)$; not only does it indicate inconsistent or nonuse of contraceptives, this relationship has also been attributed to increased hormonal levels and lower immunity during pregnancy (77). However, the results for a history of pregnancy were mixed - two studies found that nulliparity was protective against infection $(35,51)$, and two found it to be associated with an increased risk of the infection $(55,77)$, while Addiss et al $(87)$ found that women 
with one child or no children were at five times greater risk for chlamydia than women with two or more children. This may be due to involuntary infertility following 'silent' chlamydial PID. Suspected exposure to chlamydia $(24,51,52,91,110)$ or having a symptomatic partner $(32,35,71)$ is associated with an increase in risk of the infection in a number of studies, which highlights that, as chlamydia becomes more concentrated in core groups, contact tracing will become an increasingly important control strategy.

\section{IMPLICATIONS FOR FUTURE STUDIES}

There are several methodological issues that should be considered when designing further studies. First, the majority of studies were cross-sectional in design, and are therefore unable to demonstrate temporality between cause and effect. Disease and exposure status are assessed at the same time in cross-sectional studies, whereas in cohort studies, it is possible to observe whether the risk behaviour of interest preceded the infection. It should be noted, however, that the results found in the prospective cohort studies were similar to those observed in the crosssectional studies. Second, sexual behaviours were self-reported in all studies, and therefore, may be affected by recall bias and/or a social desirability bias, which is a common issue in STD research (111). Third, the sources of study subjects differed for these studies. While most studies were based in family planning clinics, many of the studies reviewed were conducted in STD clinics. STD clinic populations are fairly homogeneous, often reporting higher numbers of partners and lower SES than the general population $(112,113)$. Therefore, these populations may not be representative of the general population. However, there were no distinguishable differences in the results from STD clinics compared with the various study settings. Fourth, several different diagnostic tests of variable sensitivities and specificities (85) were used to detect $\mathrm{C}$ trachomatis in these studies. However, Gershman and Barrow (68) suggested that, although tests with lower sensitivities than the gold standard of

\section{REFERENCES}

1. Squires S, Chaly B, Wilk T, et al. Chlamydia trachomatis in Canada: An update. Can Commun Dis Rep 1997;23:113-20.

2. Schachter J, Alexander ER. Chlamydial infections. In: Evans AS, Brachman PS, eds. Bacterial Infections of Humans: Epidemiology and Control. New York: Plenum Medical Book Company, 1998:197-222.

3. Patrick DM. Chlamydia control: Components of an effective control strategy to reduce the incidence of Chlamydia trachomatis. Can J Human Sex 1997;6:143-9.

4. Reddy SP, Yeturu SR, Slupik R. Chlamydia trachomatis in adolescents: A review. J Pediatr Adolesc Gynecol 1997;10:59-72.

5. Ryan GM, Abdella TN, McNeeley G, et al. Chlamydia trachomatis infection in pregnancy and effect of treatment on outcome. Am J Obstet Gynecol 1990;162:34-9.

6. Schachter J. Biology of Chlamydia trachomatis. In: Holmes KK, Sparling PF, Mardh PA, et al, eds. Sexually Transmitted Diseases. New York: McGraw-Hill, 1999:391-405.

7. Goeree R, Gully PR. The burden of chlamydial and gonococcal infection in Canada. In: Prevention of Infertility. Ottawa: Minister of Supply and Services Canada, 1993:29-76.

8. van Dann CJ, Dallabetta G, Piot P. Prevention and control of sexually transmitted diseases in developing countries. In: Holmes KK, Sparling PF, Mardh PA, et al, eds. Sexually Transmitted Diseases. New York: McGraw-Hill, 1999:1381-90.

9. Ellen JM, Hessol NA, Kohn RP, et al. An investigation of geographic clustering of repeat cases of gonorrhea and chlamydial infection in San Francisco, 1989-1993: Evidence for core groups. J Infect Dis 1997;175:1519-22. cell culture plus a nucleic acid amplification assay may underestimate the prevalence of chlamydia in a sample, the risk factor relationships should not be substantially affected unless the tests were differentially sensitive according to exposure status. Fifth, we need to establish uniform methods of measuring these risk factors. Lastly, further studies should examine the risk factors for chlamydial infection among males. The high level of asymptomaticity and the low levels of testing among males make them an important reservoir for chlamydial infection.

\section{CONCLUSION}

The most useful demographic or behavioural risk factor for genital chlamydia is age. Adolescents, and young men and women are consistently at higher risk of being infected with chlamydia than older subjects. Chlamydia seems to be found in a diverse group of people, and does not necessarily discriminate according to racial or ethnic groups, or SES. Number of partners in the past year has been found to be positively correlated with chlamydial infection in women in several studies, although there has been no clear evidence that chlamydial infection is associated with recent number of partners, type of partners, contraceptive use or age at first intercourse.

Chlamydia is in a relatively early epidemiological stage. Like gonorrhea, as more control programs are implemented, people with limited access to preventive and treatment programs will become more dominant in the epidemic, and chlamydia may become concentrated in lower-income minority groups with high rates of partner change. A number of studies reviewed in the present article have shown that communities with wellestablished control programs are already demonstrating this pattern. More studies need to be conducted as this STD evolves through the epidemiological stages, both before and after the implementation of such programs, to ensure that preventive and treatment services are reaching those people who are most likely to be infected.
10. Orr PH, Sherman E, Blanchard J, et al. Epidemiology of infection due to Chlamydia trachomatis in Manitoba, Canada. Clin Infect Dis 1994;19:876-83.

11. Hillis SD, Nakashima AK, Marchbanks PA, et al. Risk factors for recurrent Chlamydia trachomatis infections in women. Am J Obstet Gynecol 1994;170:801-6.

12. Ellen JM, Kohn RP, Bolan GA, et al. Socio-economic differences in sexually transmitted disease rates among black and white adolescents, San Francisco, 1990 to 1992. Am J Public Health 1995;85:1546-8.

13. Jonsson M, Karlsson R, Persson K, et al. The influence of sexual and social factors on the risk of Chlamydia trachomatis infections: A population-based serologic study. Sex Transm Dis 1995;22:355-63.

14. Anderson JE, McCormick L, Fichtner R. Factors associated with self-reported STDs: Data from a national survey. Sex Transm Dis 1994:21:303-8

15. Division of STD Prevention. Sexually Transmitted Disease Surveillance, 1996. Atlanta: Centers for Disease Control and Prevention, 1997.

16. Aral SO, Holmes KK. Social and behavioural determinants of the epidemiology of STDs: Industrialized and developing countries. In: Holmes KK, Sparling PF, Mardh PA, et al, eds. Sexually Transmitted Diseases. New York: McGraw-Hill, 1999:39-76.

17. Gerbase AC, Rowley JT, Heymann DHL. Global prevalence and incidence estimates of selected curable STDs. Sex Transm Infect 
1998:74:S12-S16.

18. Division of Sexual Health Promotion and STD Prevention \& Control. STD Data Tables: Reported Genital Chlamydia Cases and Rates in Canada by Age Group and Sex, 1991-2000. Ottawa: Beaureau of HIV/AIDS, STD \& TB, Health Canada, 2001.

19. Minutes of the Provincial/Territorial Meeting of the Directors of STD Control, Ottawa, Ontario, 24 March 1998. Ottawa: Division of STD Prevention and Control, Laboratory Centre for Disease Control, Health Canada, 1998.

20. Division of STD Prevention. Sexually Transmitted Disease Surveillance, 1998. Atlanta: Centers for Disease Control and Prevention, 1999.

21. Laumann EO, Gagnon JH, Michael RT, et al. The Social Organization of Sexuality: Sexual Practices in the United States. Chicago: The University of Chicago Press, 1994.

22. Hughes G, Catchpole M. Surveillance of sexually transmitted infections in England and Wales. Eurosurveillance 1998;3:61-5.

23. Sexually transmitted diseases quarterly report: Genital Chlamydia trachomatis infection in England and Wales. Commun Dis Rep Wkly 1997;7:394-5.

24. Han Y, Coles FB, Hipp S. Screening criteria for Chlamydia trachomatis in family planning clinics: Accounting for prevalence and clients' characteristics. Fam Plann Perspect 1997;29:163-6.

25. van Duynhoven YT, van de Laar MJ, Schop WA, et al. Different demographic and sexual correlates for chlamydial infection and gonorrhoea in Rotterdam. Int J Epidemiol 1997;26:1373-85.

26. Ripa T. Epidemiologic control of genital Chlamydia trachomatis infections. Scand J Infect Dis Suppl 1990;69:157-67.

27. Anonymous. Surveillance of sexually transmitted diseases, 1989-Sweden. Wkly Epidem Rec 1990;65.

28. Egger M, Low N, Smith GD, et al. Screening for chlamydial infections and the risk of ectopic pregnancy in a county in Sweden: Ecological analysis. Br Med J 1998;316:1776-80.

29. Mardh PA. Is Europe ready for STD screening? Genitourin Med 1997;73:96-8.

30. UNAIDS. Epidemiological fact sheets on HIV/AIDS \& STDS: Sweden. Geneva: UNAIDS, 1998.

31. Kamwendo F, Forslin L, Bodin L, et al. Decreasing incidences of gonorrhea- and chlamydia-associated acute pelvic inflammatory disease. A 25-year study from an urban area of central Sweden. Sex Transm Dis 1996;23:384-91.

32. Harrison HR, Costin M, Meder JB, et al. Cervical Chlamydia trachomatis infection in university women: Relationship to history, contraception, ectopy, and cervicitis. Am J Obstet Gynecol 1985;153:244-51.

33. McCormack WM, Rosner B, McComb DE, et al. Infection with Chlamydia trachomatis in female college students. Am J Epidemiol 1985;121:107-15.

34. Burstein GR, Waterfield G, Joffe A, et al. Screening for gonorrhea and chlamydia by DNA amplification in adolescents attending middle school health centers. Opportunity for early intervention. Sex Transm Dis 1998;25:395-402.

35. Vuylsteke B, Vandenbruaene M, Vandenbulcke P, et al. Chlamydia trachomatis prevalence and sexual behaviour among female adolescents in Belgium. Sex Transm Infect 1999;75:152-5.

36. Marrazzo JM, White CL, Krekeler B, et al. Community-based urine screening for Chlamydia trachomatis with a ligase chain reaction assay. Ann Int Med 1997;127:796-803.

37. Phillips RS, Hanff PA, Holmes MD, et al. Chlamydia trachomatis cervical infection in women seeking routine gynecologic care: Criteria for selective testing. Am J Med 1989;86:515-20.

38. Bolan GA, Ehrhardt AA,Wasserheit JN. Gender perspectives and STDs. In: Holmes KK, Sparling PF, Mardh PA, et al, eds. Sexually Transmitted Diseases. New York: McGraw-Hill, 1999:117-27.

39. Berman SM, Hein K. Adolescents and STDs. In: Aral SO, Sparling PF, Mardh PA, et al, eds. Sexually Transmitted Diseases. New York: McGraw-Hill, 1999:129-42.

40. Premarital sexual experience among adolescent women - United States, 1970-1988. MMWR Morb Mortal Wkly Rep 1991;39:929-32.

41. Tanfer K. Sex and disease. Playing the odds in the 1990s. Sex Transm Dis 1994;21:S65-S72.

42. Johnson AM, Wadsworth J, Elliott P, et al. A pilot study of sexual lifestyle in a random sample of the population of Great Britain. AIDS 1989;3:135-41.
43. Turner CF, Danella RD, Rogers SM. Sexual behavior in the United States 1930-1990: Trends and methodological problems. Sex Transm Dis 1995;22:173-90.

44. Joffe GP, Foxman B, Schmidt AJ, et al. Multiple partners and partner choice as risk factors for sexually transmitted disease among female college students. Sex Transm Dis 1992;19:272-8.

45. Cates W, Rauh JL. Adolescents and sexually transmitted diseases: An expanding problem. J Adol Health Care 1985;6:257-61.

46. Cates W. The epidemiology and control of sexually transmitted diseases in adolescents. Adolesc Med 1990;1:409-27.

47. 1998 Guidelines for the Treatment of Sexually Transmitted Diseases. MMWR Morb Mortal Wkly Rep 1998;47:1-118.

48. Evans BA, Kell PD, Bond RA, et al. Heterosexual relationships and condom-use in the spread of sexually transmitted diseases to women. Genitourin Med 1995;71:291-4.

49. van den Hoek A. STDs, HIV/AIDS, ethnicity, and migrant populations. In: Aral SO, Sparling PF, Mardh PA, et al, eds. Sexually Transmitted Diseases. New York: McGraw-Hill, 1999:163-70.

50. Hart G. Risk profiles and epidemiologic interrelationships of sexually transmitted diseases. Sex Transm Dis 1993;29:126-36.

51. Hart G. Factors associated with genital chlamydial and gonococcal infection in females. Genitourin Med 1992;68:217-20.

52. Hart G. Factors associated with genital chlamydial and gonococcal infection in males. Genitourin Med 1993;69:393-6.

53. Jolly AM, Hammond G, Orr PH, et al. Risk factors for infection in women undergoing testing for Chlamydia trachomatis and Neisseria gonorrhoeae in Manitoba, Canada. Sex Transm Dis 1995;22:289-95.

54. Ramstedt K, Forssman L, Giesecke J, et al. Risk factors for Chlamydia trachomatis infection in 6810 young women attending family planning clinics. Int J STD AIDS 1992;3:117-22.

55. Stergachis A, Scholes D, Heidrich FE, et al. Selective screening for Chlamydia trachomatis infection in a primary care population of women. Am J Epidemiol 1993;138:143-53.

56. Sellors JW, Pickard L, Gafni A, et al. Effectiveness and efficiency of selective versus universal screening for chlamydial infection in sexually active young women. Arch Intern Med 1992;152:1837-44.

57. Rice RJ, Roberts PL, Handsfield HH, et al. Socio-demographic distribution of gonorrhea incidence: Implications for prevention and behavioural research. Am J Public Health 1991;81:1252-8.

58. Becker KM, Glass GE, Brathwaite W, et al. Geographic epidemiology of gonorrhea in Baltimore, Maryland, using a geographic information system. Am J Epidemiol 1998;147:709-16.

59. Lacey CJ, Merrick DW, Bensley DC, et al. Analysis of the sociodemography of gonorrhoea in Leeds, 1989-93. Br Med J 1997;314:1715-8.

60. Zimmerman HL, Potterat JJ, Dukes RL, et al. Epidemiologic differences between chlamydia and gonorrhea. Am J Public Health 1990;80:1338-42.

61. Blanchard JF, Moses S, Greenaway C, et al. The evolving epidemiology of chlamydial and gonococcal infections in response to control programs in Winnipeg, Canada. Am J Public Health 1998;88:1496-502.

62. Wasserheit JN, Aral SO. The dynamic topology of sexually transmitted disease epidemics: Implications for prevention strategies. J Infect Dis 1996;174:S201-13.

63. Greenberg J, Magder L, Aral SO. Age at first coitus. A marker for risky sexual behaviour in women. Sex Transm Dis 1992;19:331-4.

64. Quinn RW, O'Reilly KR, Khaw M. Gonococcal infections in women attending the venereal disease clinic of the Nashville Davidson County Metropolitan Health Department, 1984. South Med J 1988;81:851-4.

65. Canadian Guidelines for the Prevention, Diagnosis, Management and Treatment of Sexually Transmitted Diseases in Neonates, Children, Adolescents and Adults. Can Commun Dis Rep 1992;18:81-90

66. Toomey KE, Moran JS, Rafferty MP, et al. Epidemiological considerations of sexually transmitted diseases in underserved populations. Infect Dis Clin North Am 1993;7:739-52.

67. St Louis ME, Holmes KK. Conceptual framework for STD/HIV prevention and control. In: Holmes KK, Sparling PF, Mardh PA, et al, eds. Sexually Transmitted Diseases. New York: McGraw-Hill, 1999:1239-53 
68. Gershman KA, Barrow JC. A tale of two sexually transmitted diseases. Prevalences and predictors of chlamydia and gonorrhea in women attending Colorado family planning clinics. Sex Transm Dis 1996;23:481-8.

69. Mosure DJ, Berman S, Kleinbaum D, et al. Predictors of Chlamydia trachomatis infection among female adolescents: A longitudinal analysis. Am J Epidemiol 1996;144:997-1003.

70. Handsfield HH, Jasman LL, Roberts PL, et al. Criteria for selective screening for Chlamydia trachomatis infection in women attending family planning clinics. JAMA 1986;255:1730-4.

71. Addiss DG, Vaughn ML, Holzhueter MA, et al. Selective screening for Chlamydia trachomatis infection in nonurban family planning clinics in Wisconsin. Fam Plann Perspect 1987;19:252-6.

72. Winter L, Goldy S, Baer C. Prevalence and epidemiologic correlates of Chlamydia trachomatis in rural and urban populations. Sex Transm Dis 1990;17:30-6.

73. Han Y, Morse DL, Lawrence CE, et al. Risk profile for chlamydia infection in women from public health clinics in New York State. J Community Health 1993;18:1-9.

74. Karam GH, Martin DH, Flotte TR, et al. Asymptomatic Chlamydia trachomatis infections among sexually active men. J Infect Dis 1986;154:900-3

75. Use of race and ethnicity in public health surveillance. MMWR Morb Mortal Wkly Rep 1993;42:1-17.

76. Chlamydia prevalence and screening practices - San Diego County, California, 1993. MMWR Morb Mortal Wkly Rep 1994:43:366-9.

77. Munk C, Morre S, Kjaer SK, et al. PCR-detected Chlamydia trachomatis infections from the uterine cervix of young women from the general population: Prevalence and risk determinants. Sex Transm Dis 1999;26:325-8.

78. Hook EW, Reichart CA, Upchurch DM, et al. Comparative behavioral epidemiology of gonococcal and chlamydial infections among patients attending a Baltimore, Maryland, sexually transmitted disease clinic. Am J Epidemiol 1992;136:662-72.

79. Pereira LH, Embil JA, Haase DA, et al. Cytomegalovirus infection among women attending a sexually transmitted disease clinic: association with clinical symptoms and other sexually transmitted diseases. Am J Epidemiol 1990;131:683-92.

80. Brunham RC, Plummer FA. A general model of sexually transmitted disease epidemiology and its implications for control. Med Clin North Am 1990;74:1339-52

81. Addiss DG, Vaughn ML, Ludka D, et al. Decreased prevalence of Chlamydia trachomatis infection associated with a selective screening program in family planning clinics in Wisconsin Sex Transm Dis 1993;20:28-35.

82. Burstein GR, Gaydos CA, Diener-West M, et al. Incident Chlamydia trachomatis infections among inner-city adolescent females. JAMA 1998;280:521-6.

83. Tanfer K, Grady WR, Klepinger DH, et al. Condom use among U.S. Men, 1991. Fam Plann Perspect 1993;25:61-6.

84. Rowley J, Berkley S. Sexually transmitted diseases. In: Murray CJL, Lopez AD, eds. Health Dimensions of Sex and Reproduction: The Global Burden of Sexually Transmitted Diseases, HIV, Maternal Conditions, Perinatal Disorders, and Congenital Anomalies. New York: World Health Organization, 1998:19-110.

85. Stamm WE. Chlamydia trachomatis infections of the adult. In: Holmes KK, Sparling PF, Mardh PA, et al, eds. Sexually Transmitted Diseases. New York: McGraw-Hill, 1999:407-22.

86. Anderson JE, Dahlberg LL. High-risk sexual behavior in the general population: Results from a national survey, 1988-1990. Sex Transm Dis 1992;19:320-5.

87. Addiss DG, Vaughn ML, Golubjatnikov R, et al. Chlamydia trachomatis infection in women attending urban Midwestern family planning and community health clinics: Risk factors, selective screening, and evaluation of non-culture techniques. Sex Transm Dis 1990;17:138-46.

88. Humphreys JT, Henneberry JF, Rickard RS, et al. Cost-benefit analysis of selective screening criteria for Chlamydia trachomatis infection in women attending Colorado family planning clinics. Sex Transm Dis 1992;19:47-53.

89. Mosure DJ, Berman S, Fine D, et al. Genital chlamydia infections in sexually active female adolescents: Do we really need to screen everyone? J Adolesc Health 1997;20:6-13

90. Weinstock HS, Bolan GA, Kohn R, et al. Chlamydia trachomatis infection in women: A need for universal screening in high prevalence populations? Am J Epidemiol 1992;135:41-7.

91. Bro F, Juul S. Predictors of Chlamydia trachomatis infection in women in general practice. Fam Pract 1990;7:138-43.

92. Evans BA, Tasker T, MacRae KD. Risk profiles for genital infection in women. Genitourin Med 1993;69:257-61.

93. Finelli L, Nakashima AK, Hillis S, et al. Selective screening versus presumptive treatment criteria for identification of women with chlamydial infection in public clinics: New Jersey. Am J Obstet Gynecol 1996;174:1527-33.

94. Johnson BA, Poses RM, Fortner CA, et al. Derivation and validation of a clinical diagnostic model for chlamydial cervical infection in university women. JAMA 1990;264:3161-5.

95. Malotte CK, Wiesmeier E, Gelineau KJ. Screening for chlamydia cervicitis in a sexually active university population. Am J Public Health 1990;80:469-71.

96. Thewessen EA, van der Meijden WI, Doppenberg HJ, et al. Screening for cervical Chlamydia trachomatis infections in two Dutch populations. Genitourin Med 1990;66:361-6.

97. Oakeshott P, Kerry S, Hay S, et al. Opportunistic screening for chlamydial infection at time of cervical smear testing in general practice: Prevalence study. Br Med J 1998;316:351-2.

98. Prins M, Hooykaas C, Coutinho RA, et al. Incidence and risk factors for acquisition of sexually transmitted diseases in heterosexuals with multiple partners. Sex Transm Dis 1994;21:258-67.

99. Oh MK, Cloud GA, Fleenor M, et al. Risk for gonococcal and chlamydial cervicitis in adolescent females: Incidence and recurrence in a prospective cohort study. J Adolesc Health 1996;18:270-5.

100. Stone KM, Timyan J,Thomas EL. Barrier methods for the prevention of sexually transmitted diseases. In: Aral SO, Sparling PF, Mardh PA, et al, eds. Sexually Transmitted Diseases. New York: McGraw-Hill, 1999:1307-21.

101. Oh MK, Feinstein RA, Soileau EJ, et al. Chlamydia trachomatis cervical infection and oral contraceptive use among adolescent girls. J Adolesc Health 1989;10:376-81.

102. Cottingham J, Hunter D. Chlamydia trachomatis and oral contraceptive use: A quantitative review. Genitourin Med 1992;68:209-16.

103. Masse R, Laperriere H, Rousseau H, et al. Chlamydia trachomatis cervical infection: Prevalence and determinants among women presenting for routine gynecologic examination. Can Med Assoc J 1991;145:953-61.

104. Rahm VA, Odlind V, Pettersson R. Chlamydia trachomatis in sexually active teenage girls. Factors related to genital chlamydia infection: A prospective study. Genitourin Med 1991;67:317-21.

105. Kost K, Forrest JD. American women's sexual behaviour and exposure to risk of sexually transmitted diseases. Fam Plann Perspect 1992;24:244-54

106. Evans BA, Bond RA, MacRae KD. Sexual relationships, risk behaviour, and condom use in the spread of sexually transmitted infections to heterosexual men. Genitourin Med 1997;73:368-72.

107. Kirby D, Short L, Collins J, et al. School-based programs to reduce sexual risk behaviours: A review of effectiveness. Pub Health Rep 1994:109:339-60.

108. Smith TW. Adult sexual behaviour in 1989: Number of partners, frequency of intercourse and risk of AIDS. Fam Plann Perspect 1991;23:102-7.

109. Seidman SN, Mosher WD, Aral SO. Women with multiple sexual partners: United States, 1988. Am J Public Health 1992;82:1388-94.

110. Vincelette J, Baril JG, Allard R. Predictors of chlamydial infection and gonorrhea among patients seen by private practitioners. Can Med Assoc J 1991;144:713-21.

111. Aral SO. Sexual behavior in sexually transmitted disease research. Sex Transm Dis 1994;21:S59-S64.

112. Johnson AM, Wadsworth J, Wellings K, et al. Who goes to sexually transmitted disease clinics? Results from a national population survey. Genitourin Med 1996;72:197-202.

113. Catchpole M, Connor N, Brady A, et al. Behavioural and demographic characteristics of attenders at two genitourinary medicine clinics in England. Genitourin Med 1997;73:457-61. 